\title{
UJI AKTIVITAS SEDIAAN KRIM EKSTRAK ETANOL HERBA SELEDRI (Apium graveolens L.) TERHADAP LUKA SAYAT PADA KELINCI (Oryctolagus cuniculus L.)
}

\author{
Agust Dwi Djajanti ${ }^{1}$ ), Dzul Asfi ${ }^{1}$ ) \\ 1) Akademi Farmasi Yamasi Makassar \\ Email : mamasasa71@gmail.com
}

\begin{abstract}
Research has been carried out on the activity test of preparations for the ethanol extract of celery herbs (Apium graveolens $L$.) on vegetable wounds on rabbits (Oryctolagus cuniculus L). The aim of this study was to determine the activity of cream preparations for celery herb extract using concentrations of $2 \% \mathrm{~b} / \mathrm{v}, 4 \% \mathrm{~b} / \mathrm{v}$ and negative controls. The activity test was carried out on 2 rabbit test animals by carrying out the same 3 incisions on each rabbit's back with a length of $2 \mathrm{~cm}, 0.3 \mathrm{~cm}$ depth and 1 incision wound for negative control. The observation was carried out to see the pharmacological effects of the cream preparation, namely anti-inflammatory effect, proliferation, and its remodeling as an anti-inflammatory effect is swollen or red, while the proliferation effect is the formation of stopped granulation tissue after the entire surface is covered in the epithelium and the process of wound maturation, and while the remodeling effect is the phase that ends when the inflammation sign is gone.
\end{abstract}

Keywords: Activity, Ethanol Extract, Herbs Celery (Apium graveolens L.), Cut wounds, Rabbits (Oryctolagus cuniculus L.)

\section{ABSTRAK}

Telah dilakukan penelitian tentang Uji Aktivitas Sediaan Krim Ekstrak Etanol Herba Seledri (Apium graveolens L.) Terhadap Luka Sayat Pada Kelinci (Oryctolagus cuniculus L). Penelitian ini bertujuan untuk mengetahui aktivitas sediaan krim ekstrak herba seledri dengan menggunakan konsentrasi $2 \% \mathrm{~b} / \mathrm{v}, 4 \% \mathrm{~b} / \mathrm{v}$ dan kontrol negatif. Uji aktivitas dilakukan pada 2 hewan uji kelinci dengan melakukan 3 luka sayat yang sama disetiap punggung kelinci dengan panjang $2 \mathrm{~cm}$, kedalaman $0,3 \mathrm{~cm}$ dan 1 luka sayatan untuk kontrol negatif pengamatan dilakukan untuk melihat efek farmakologi dari sediaan krim tersebut yaitu efek anti inflamasi, proliferasi, dan remodelingnya yang dimaksud efek anti inflamasi adalah bengkak atau merah, sedangkan efek proliferasi adalah pembentukan jaringan granulasi berhenti setelah seluruh permukaan tertutup epitel dan proses pendewasaan luka, dan sedangkan efek remodelingnya adalah fase yang berakhir bila tanda radang sudah hilang.

Kata kunci : Aktivitas, Ekstrak etanol, Herba Seledri (Apium graveolens L.), Luka sayat, Kelinci (Oryctolagus cuniculus L.)

\section{PENDAHULUAN}

Obat tradisional adalah bahan atau ramuan bahan yang berupa bahan tumbuhan, bahan hewan, bahan mineral, sediaan sarian (galenik) atau campuran dari bahan tersebut yang secara turuntemurun telah digunakan untuk pengobatan berdasarkan pengalaman (UU No. 23 tahun 1992). Lebih dari 5000 tahun yang lalu, tahaman herla telah digunakan untuk pengobatan tradisional maupun non-tradisional (Koehn, F. E. \& Carter, G. $\mathrm{T}$, 2005). Dalam Sistem Kesehatan Nasional disebutkan bahwa obat tradisional yang terbukti berhasil guna harus dimanfaatkan dalam pelayanan kesehatan. WHO merekomendasi penggunaan obat tradisional termasuk herbal dalam pemeliharaan kesehatan masyarakat, pencegahan dan pengobatan penyakit.

Selain itu, juga mendukung upaya-upaya dalam peningkatan keamanan dan khasiat dari obat tradisional.Penggunaan obat tradisional secara umum dinilai lebih aman dari pada penggunaan obat modern. Hal ini disebabkan karena obat tradisional memiliki efek samping yang relatif lebih sedikit dan relatif lebih aman dari pada obat modern (Katno dan Pramono, 2002). Selain itu, dengan adanya perkembangan ilmu pengetahuan dan teknologi, obat tradisional juga mengalami perkembangan dalam bentuk formulasi sediaan misalnya serbuk, pil, kapsul dan lain-lain (Pudjiastuti et al., 1996).

Dalam perkembangannya, berbagai temuan riset pengobatan tradisional mampu menemukan beberapa alternatif penyembuhan berbagai penyakit, diantaranya adalah sebagai obat penyembuhan luka. Luka merupakan suatu keadaan terputusnya kontinuitas jaringan tubuh, yang dapat menyebabkan terganggunya fungsi tubuh sehingga mengganggu aktivitas sehari-hari. Luka sendiri terbagi menjadi beberapa jenis yaitu ada luka terbuka dan luka tertutup, luka disebut tertutup jika tidak terjadi robekan sedangkan luka terbuka jika terjadi robekan dan kelihatan contohnya luka gores atau luka sayat (Damayanti, Ika putri dkk 15).

Ada berbagai macam obat penyembuhan luka yang biasa digunakan oleh masyarakat, baik berupa obat tradisional maupun sintetik. Contoh sediaan obat luka atau luka infeksi yang paling umum dan sering digunakan adalah Obat yang biasa digunakan untuk menyembuhkan luka sayat seperti Povidone ionide, Betadine, Bioplacenton, Carboxy Methyl Cellulose, dan Neomycin Sulfat (Kristiana Hery, 2008)

Beberapa jenis tanaman yang difungsikan untuk mengobat.i luka.Salah satunya adalah 
tanaman seledri. Seledri dapat tumbuh dengan baik pada kondisi iklim ringan ditanah lempung berpasir (Sowbhagya, H. B, 2014). Seledri mengandung flavonoid. Flavonoid bisa digunakan antialergi, antifinflamasi, antivirus, dan antikarsinogenik dan antioksidan yang potensial untuk mencegah pembentukan radikal bebas (Ronald et al., 2000)

Seledri dapat difungsikan sebagai obat luka karena mengandung senyawa vitamin $\mathrm{K}$. Dimana vitamin $\mathrm{k}$ berfungsi sebagai pembekuan darah pada fase pertama dari proses penyembuhan luka (Sjamsuhidajat, 2005).

Penggunaan daun seledri dapat diformulasi dalam berbagai bentuk sediaan contohnya sediaan krim, dalam penelitian ini akan diuji efek dari sediaan krim ekstrak herba seledri menggunakan kelinci, Penelitian ini bertujuan untuk mengetahui pengaruh konsentrasi krim ekstrak etanol herba seledri (Apium graveolens $\mathrm{L}$ ) terhadap penyembuhan luka.

Hasil penelitian ini diharapkan dapat memberikan informasi kepada masyarakat mengenai konsentrasi krim ekstrak etanol daun seledri (Apium graveolens L) dapat digunakan sebagai penyembuhan luka.

\section{Rumusan Masalah}

Berdasarkan uraian diatas maka permasalahan dalam penelitian ini adalah apakah sediaan krim ekstrak etanol herba seledri (Apium graveolens $L$ ) dapat menyembuhkan luka sayat pada kelinci (Oryctolagus cuniculus L.).

\section{Tujuan Penelitian}

Untuk mengetahui aktivitas sediaan krim ekstrak etanol herba seledri (Apium graveolensL) terhadap luka sayat pada kelinci (Oryctolagus cuniculus L.).

\section{Manfaat Penelitian}

Adapun manfaat penelitian ini adalah diharapkan menjadi sumber informasi sekaligus pengetahuan lebih bagi masyarakat tentang pemanfaatan daun seledri (Apium graveolens $L$ ) untuk digunakan dalam proses penyembuhan luka.

\section{Jenis Penelitian}

Jenis penelitian ini merupakan penelitian eksperimen laboratorium dengan melakukan serangkaian untuk mengamati dan menguji aktivitas krim herba seledri (Apium graveolens L) terhadap penyembuhan luka sayat pada kelinci (Oryctolagus cuniculus L).

\section{Tempat dan Waktu Penelitian}

Penelitian ini telah dilakukan di laboratorium Farmasetika dan Farmakologi Jurusan Akademi Farmasi Yamasi Makassar mulai dari bulan Agustus-September 2018.

Pengambilan sampel

Bahan uji Herba Seledri (Apium graveolens L.) diperoleh dari Desa Kalebajeng Kecamatan Bajeng Kabupaten Gowa.

\section{Pengolahan Sampel}

Bahan uji Herba Seledri disortasi basah yaitu pemisahan dari tanah, kerikil, daun, akar yang telah rusak serta pengotor-pengotor lainnya. Kemudian dicuci hingga bersih. Kemudian dilakukan proses perajangan yaitu proses pemotongan simplisia menjadi bagian bagian kecil tujuannya memudahkan proses pengeringan, setelah itu bahan uji dikeringkan dengan cara dianginanginkan terhindar dari sinar matahari langsung. Selanjutnya bahan uji disortasi kering, yaitu dipisahkan dari benda-benda asing dan pengotorpengotor lain yang masih ada dan tertinggal pada simplisia kering.

\section{Pengujian Terhadap Hewan Coba}

Efek penyembuhan luka dilakukan terhadap hewan coba kelinci yang sehat, langkah pertama yang dilakukan adalah mencukur bulunya kemudian dianastesi dengan menggunakan etil klorida spray dan dibuat luka sayat sepanjang 2 cmdengan cara disayat, melukai atau menggores punggung kelinci dengan scaple dengan kedalaman $0.3 \mathrm{~cm}$.

Masing-masing luka pada kelinci akan diberikan perlakuan seperti gambar. 
A

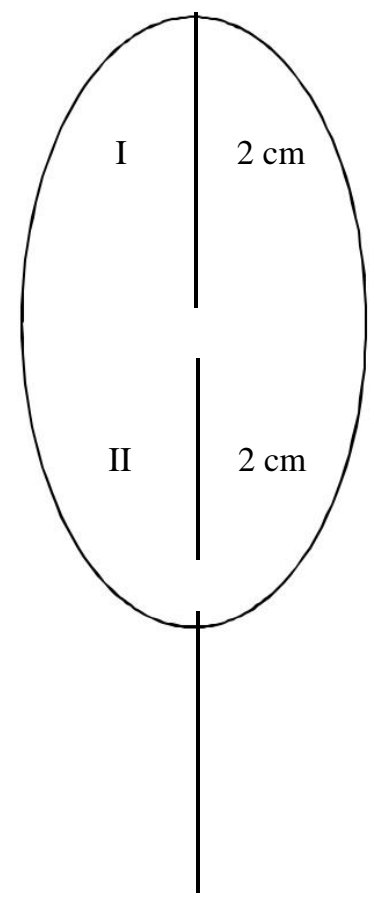

B

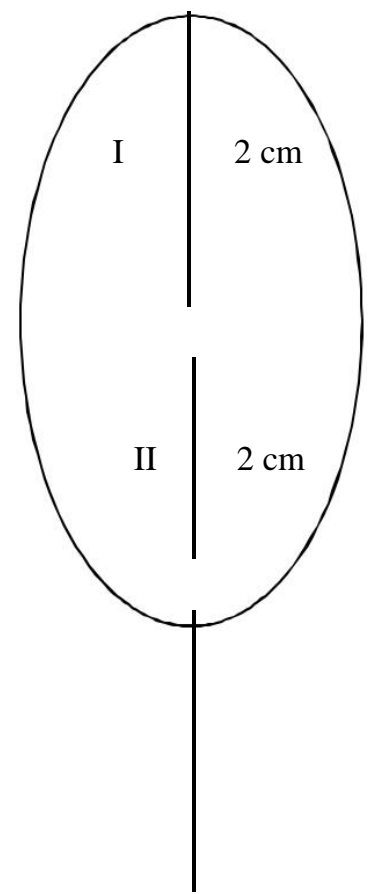

Keterangan :

Gambar 2. Model perlakuan luka sayat pada Kelinci

I : Luka dioleskan merata dengan krim yang mengandung ekstrak daun seledri dengan konsentrasi2\%

II :Luka dioleskan merata dengan krim yang mengandung ekstrak daun seledri dengan konsentrasi $4 \%$

III : Luka dioleskan merata dengan basis krimsebagai kontrol negatif.

Setelah itu pada masing-masing kelompok luka kelinci dioleskan sediaan krim pada punggung Kelinci yang dilukai dengan frekuensi 2 kali sehari (pagi dan sore) dan kemudian ditutup dengan kasa dan plaster. Diukur diameter luka dimulai hari kedua dengan mistar. Pengukuran dilakukan tiap hari dimulai dari hari kedua sampai luka dinyatakan sembuh. Luka dianggap sembuh bila diameter luka mencapai $0 \mathrm{~cm}$ terdekat atau telah berbentuk jaringan baru yang menutupi luka.

Pengamatan Penyembuhan Luka Sayat

Proses penyembuhan luka sayat dilakukan dengan mengamati fase inflmasi, fase poliferasi, fase remodeling, dan diameter luka sayat tiap harinya selama 7 hari dan diukur panjang luka tiap hari. 


\section{HASIL PENELITIAN}

Hasil proses penyembuhan luka pada kelinci sebagai berikut :

\begin{tabular}{|c|c|c|c|c|c|c|}
\hline HARI & $\begin{array}{c}\text { HEWAN } \\
\text { UJI }\end{array}$ & $\begin{array}{c}\text { PANJANG } \\
\text { LUKA }\end{array}$ & $\begin{array}{c}\text { KRIM } \\
\text { SELEDRI } \\
2 \%\end{array}$ & $\begin{array}{c}\text { KRIM } \\
\text { SELEDRI } \\
4 \%\end{array}$ & $\begin{array}{l}\text { KONTROL } \\
\text { NEGATIF }\end{array}$ & KET \\
\hline 1 & Kelinci 1 & $2 \mathrm{~cm}$ & $\begin{array}{l}- \\
+ \\
+\end{array}$ & $\begin{array}{l}- \\
+ \\
+\end{array}$ & $\begin{array}{l}- \\
+ \\
+\end{array}$ & $\begin{array}{l}\text { Inflamasi } \\
\text { Proliferasi } \\
\text { Remodelling }\end{array}$ \\
\hline 2 & Kelinci 1 & $2 \mathrm{~cm}$ & $\begin{array}{l}- \\
+ \\
+\end{array}$ & $\begin{array}{l}- \\
+ \\
+\end{array}$ & $\begin{array}{l}- \\
+ \\
+\end{array}$ & $\begin{array}{l}\text { Inflamasi } \\
\text { Proliferasi } \\
\text { Remodelling }\end{array}$ \\
\hline 3 & Kelinci 1 & $2 \mathrm{~cm}$ & $\begin{array}{l}- \\
+ \\
+\end{array}$ & $\begin{array}{l}- \\
+ \\
+\end{array}$ & $\begin{array}{l}- \\
+ \\
+\end{array}$ & $\begin{array}{l}\text { Inflamasi } \\
\text { Proliferasi } \\
\text { Remodelling }\end{array}$ \\
\hline 4 & Kelinci 1 & $1,5 \mathrm{~cm}$ & $\begin{array}{l}+ \\
+\end{array}$ & $\begin{array}{l}+ \\
+\end{array}$ & - & $\begin{array}{l}\text { Inflamasi } \\
\text { Proliferasi } \\
\text { Remodelling }\end{array}$ \\
\hline 5 & Kelinci 1 & $1 \mathrm{~cm}$ & $\begin{array}{l}+ \\
- \\
+\end{array}$ & $\begin{array}{l}+ \\
- \\
+\end{array}$ & $\begin{array}{l}- \\
- \\
+\end{array}$ & $\begin{array}{l}\text { Inflamasi } \\
\text { Proliferasi } \\
\text { Remodelling }\end{array}$ \\
\hline 6 & Kelinci 1 & $1 \mathrm{~cm}$ & $\begin{array}{l}+ \\
+ \\
-\end{array}$ & $\begin{array}{l}+ \\
+ \\
-\end{array}$ & $\begin{array}{l}- \\
+ \\
+\end{array}$ & $\begin{array}{l}\text { Inflamasi } \\
\text { Proliferasi } \\
\text { Remodelling }\end{array}$ \\
\hline 7 & Kelinci 1 & $1 \mathrm{~cm}$ & $\begin{array}{l}+ \\
+ \\
-\end{array}$ & $\begin{array}{l}+ \\
+ \\
-\end{array}$ & $\begin{array}{l}- \\
+ \\
-\end{array}$ & $\begin{array}{l}\text { Inflamasi } \\
\text { Proliferasi } \\
\text { Remodelling }\end{array}$ \\
\hline
\end{tabular}

Sumber : Data primer 2018

\begin{tabular}{|c|c|c|c|c|c|c|}
\hline $\begin{array}{l}\mathrm{HA} \\
\mathrm{RI}\end{array}$ & $\begin{array}{c}\text { HEWAN } \\
\text { UJI }\end{array}$ & $\begin{array}{c}\text { PANJANG } \\
\text { LUKA }\end{array}$ & $\begin{array}{c}\text { KRIM } \\
\text { SELEDRI } \\
2 \%\end{array}$ & $\begin{array}{c}\text { KRIM } \\
\text { SELEDRI } \\
4 \%\end{array}$ & $\begin{array}{c}\text { KONTROL } \\
\text { NEGATIF }\end{array}$ & FASE \\
\hline 1 & Kelinci 2 & $2 \mathrm{~cm}$ & $\begin{array}{l}- \\
+ \\
+\end{array}$ & $\begin{array}{l}- \\
+ \\
+\end{array}$ & $\begin{array}{l}- \\
+ \\
+\end{array}$ & $\begin{array}{l}\text { Inflamasi } \\
\text { Proliferasi } \\
\text { Remodelling }\end{array}$ \\
\hline 2 & Kelinci 2 & $2 \mathrm{~cm}$ & $\begin{array}{l}- \\
+ \\
+\end{array}$ & $\begin{array}{l}- \\
+ \\
+\end{array}$ & $\begin{array}{l}- \\
+ \\
+\end{array}$ & $\begin{array}{l}\text { Inflamasi } \\
\text { Proliferasi } \\
\text { Remodelling }\end{array}$ \\
\hline
\end{tabular}




\begin{tabular}{|l|l|l|l|l|l|l|} 
& & & & & & \\
\hline
\end{tabular}

Sumber : Data primer 2018

\section{PEMBAHASAN}

Pada percobaan luka sayat terhadap kelinci 1 dengan panjang $2 \mathrm{~cm}$ dan dilakukan pengujian selama 7 hari, maka didapatkan hasil yaitu hari pertama sampai hari ketiga mengalami fase inflamasi dimana inflamasi adalah mediator terjadinya peradangan.

Dari masing-masing krim seledri dengan konsentrasi $2 \%$ dan $4 \%$ dan krim tanpa ekstrak belum terjadi perubahan dan diameter panjang lukanya masih $2 \mathrm{~cm}$ Kemudian pada hari keempat mengalami perubahan ukuran panjang dari $2 \mathrm{~cm}$ menjadi $1.5 \mathrm{~cm}$ pada krim seledri $2 \%$ dan krim seledri $4 \%$ mengalami fase proliferasi dimana proliferasi adalah tahap dimana tepi luka mulai menyempit sedangkan pada krim tanpa ekstrak mengalami dua fase antara fase inflamasi dan fase proliferasi berarti pada hari ini menunjukkan bahwa penambahan ekstrak seledri lebih berefek dibandingkan dengan tanpa ekstrak Pada hari kelima sampai hari ketujuh terjadi perubahan ukuran dari yang panjangnya $1.5 \mathrm{~cm}$ menjadi 1 $\mathrm{cm}$ pada krim seledri $2 \%$ dan $4 \%$ dihari yang kelima mengalami fase proliferasi berbeda dengan krim tanpa ekstrak yang mengalami dua fase yaitu fase inflamasi dan fase proliferasi berarti terlihat perbedaan lagi dan Pada hari keenam dan ketujuh pada krim seledri $2 \%$ dan $4 \%$ mengalami fase remodeling dimana remodeling adalah fase penyudahan atau radang sudah hilang.tetapi berbeda dengan tanpa ekstrak yang masih mengalami fase inflamasi.

Pada kelinci 2 dengan luka sayat pada diameter panjang $2 \mathrm{~cm}$ dan dilakukan pengujian selama 7 hari maka didapatkan hasil yaitu, hari pertama sampai hari ketiga mengalami fase inflamasi / radang, Kemudian pada hari keempat dengan diameter panjang yang masih sama yaitu $2 \mathrm{~cm}$ mengalami fase proliferasi baik itu krim seledri $2 \%$ dan $4 \%$ maupun tanpa ekstrak hasilnya sama dan pada hari kelima dan keenam terjadi perubahan ukuran dengan panjang $1.5 \mathrm{~cm}$ tetapi yang berbeda disini adalah pada hari kelima dengan krim seledri $2 \%$ dan $4 \%$ mengalami fase proliferasi sedangkan pada krim tanpa ekstrak masih mengalami fase inflamasi. Dan pada hari keenam dengan krim seledri $2 \%$ dan $4 \%$ mengalami fase remodeling 
tetapi krim tanpa ekstrak masih mengalami fase inflamasi, kemudian hari ketujuh mengalami perubahan ukuran diameter panjang dari $2 \mathrm{~cm}$ menjadi $1 \mathrm{~cm}$ pada krim seledri $2 \%$ dan $4 \%$ mengalami fase remodeling tetapi pada krim tanpa ekstrak masih mengalami inflamasi dengan ini menandakan bahwa adanya pengaruh penyembuhan luka menggunakan ekstrak seledri dibandingkan dengan tanpa ekstrak dengan ini pula ekstrak seledri maka luka dipunggung kelinci lebih cepat sembuh di bandingkan tanpa ekstrak.

Pada luka kelinci 1 dan kelinci 2 mempunyai variasi biologis yang mungkin berpengaruh pada sistem imun yang berbeda atau volume makanan yang berbeda, berat badan,lapisan kulit yang relatif tebal,faktor lingkungan atau faktor lain yang memungkinkan luka lebih cepat sembuh.

\section{KESIMPULAN}

Berdasarkan hasil penelitian dan pembahasan disimpulkan bahwa krim ekstrak seledri dengan konsentrasi $2 \%$ dan $4 \%$ mempunyai aktivitas menyembuhkan luka sayat pada kelinci.

\section{SARAN}

Disarankan untuk melakukan penelitian lebih lanjut dengan konsentrasi yang lebih besar dengan waktu pengamatan sampai sembuh total

\section{DAFTAR PUSTAKA}

Anwar, 2012, Eksipien Dalam Sediaan Farmasi Karakterisasi dan Aplikasi, Penerbit Dian Rakyat, Jakarta

Baroroh, dwi. 'Konsep Luka Pdf'. Psik fikes MM. 2011. Hal:2

Damayanti,Ika Putri dkk. 2015. Keterampilan Dasar Kebidanan II. Deepublish (Group Penerbitan CV. Budi Utama): Yogyakarta

Hidayat, Syamsul dan Rodame M. Napitupulu. 2015. Kitab TumbuhanObat.Jakarta: Agriflo.

Hustamin, Rudy. Panduan Memelihara Kelinci Hias, : Jakarta : Penerbit Agro Media
Pusaka. 2006 Uji Efektivitas Gel Ekstrak Etanol Daun Alpukat Sebagai Obat Luka Sayat Pada Kelinci.

Ir.Rahmat rukmana 2011, Bertanam seledri,

Katno dan Pramono S. 2002. Tingkat Manfaat dan Keamanan Tanaman Obat dan Obat Tradisional. Fakultas Farmasi Universitas Gadjah Mada. (diakses April 2018)

Kemenkes. 2013. Farmakope Indonesia Edisi V.Kementrian Kesehatan RI: Jakarta

Koehn, F. E. \& Carter, G. T. 2005. "The evolving role of natural products in drug discovery. Nat. Rev. Drug Discov. : 4:206-220.

Kristiana, Hery. 2008. Gambaran Darah Mencit (Mus musculus albinus) yang Diberi Salep Ekstrak Etanol dan Fraksi Hexan Rimpang Kunyit (Curcuma longa Linn.) pada Proses Persembuhan Luka. Skripsi. Fakultas Kedoteran Hewan Institut Pertanian Bogor. Bogor.

Pudjiastuti, Dzulkarnain B., Nuratmi B.. 1996. Uji Analgetik Infus Rimpang Lempuyang Pahit (Zingiber americana BL) pada Mencit Putih.(diakses April 2018)

Ronald I., Prior C., Cao G. 2000. Antioxidant Phytochemicals in Fruit and vegetables: Diet and Health Implications. Horticulture Science, 5(4): 588-592

Sjamsuhidajat, Wim de Jong. 2005. Buku Ajar IImu Bedah, Edisi II. Jakarta: EGC.

Sowbhagya, H. B. 2014. "Chemistry, Technology, and Nutraceutical Functions of Celery (Apium Graveolens L.): An Overview." Critical Reviews in Food Science and Nutrition 54(3):389-98

Sudarsono, Agus P, Didik G, dkk. 1996. Tumbuhan Obat. Yogyakarta : UGM. 